\title{
Characterization of whey protein isolate obtained from milk microfiltration permeate
}

\author{
M Britten ${ }^{1}$, Y Pouliot ${ }^{2}$ \\ ${ }^{1}$ Agriculture and Agri-Food Canada, Food Research and Development Centre, 3600, Casavant \\ Blvd West, St Hyacinthe, Quebec, Canada, J2S 8E3; ${ }^{2}$ Centre de recherche en sciences et \\ technologie du lait (STELA) Université Laval, Sainte-Foy, Quebec, Canada, G1K 7P4
}

(Received 5 April 1995; accepted 20 July 1995)

\begin{abstract}
Summary - Whey protein was concentrated from milk microfiltration permeate or Cheddar cheese whey using batch ultrafiltration and diafiltration. Permeate flux declined more rapidly for milk microfiltrate during concentration, but similar flux profiles were observed on both wheys during diafiltration. Protein contents in concentrates from milk microfiltrate and cheese wheys were respectively 95 and $74 \%$ on a dry matter basis, while their fat contents were respectively 0.2 and $15 \%$. Protein solubility of the milk microfiltrate isolate was over $95 \%$ between $\mathrm{pH} 3$ and 8 , while protein solubility of cheese whey concentrate varied between 75 and $90 \%$ over the same $\mathrm{pH}$ range. $\beta$-Lactoglobulin in cheese whey concentrate showed extensive structural alteration as evidenced by the low proportion of $\mathrm{SH}$ groups in native position. $\beta$-Lactoglobulin structural alteration was less severe in protein isolated from milk microfiltrate, but still significant. Milk microfiltrate protein isolate showed better gelling properties than cheese whey protein concentrate. Cheese whey protein concentrate did not foam at all, while stiff and stable foams were produced from milk microfiltrate protein isolate. Gelation and foaming were very sensitive to the ionic environment and were controlled by a balance between the $\mathrm{pH}$ and the calcium concentration. Reduction of calcium content in milk microfiltrate protein isolate, using saline solution during diafiltration, had only slight effects of protein functional properties.
\end{abstract}

milk microfiltration / whey protein / ultrafiltration / heat set gelation / foaming property

Résumé - Caractérisation d'un isolat protéique de lactosérum obtenu à partir d'un perméat de microfiltration de lait. Les protéines d'un perméat de microfiltration de lait et d'un lactosérum de fromage Cheddar ont été concentrées par ultrafiltration en batch suivie d'une diafiltration. La comparaison des flux de microfiltration indique un colmatage plus rapide pendant la concentration du microfiltrat de lait. Les flux de perméation en fin de concentration et pendant la diafiltration étaient toutefois similaires. Les teneurs en protéines des concentrés protéiques de microfiltrat de lait et de lactosérum fromager étaient respectivement de 95 et $74 \%$, alors que les concentrations lipidiques atteignaient respectivement 0,2 et $15,5 \%$. La solubilité des isolats de microfiltrat de lait était supérieure à $95 \%$ entre $\mathrm{pH} 3$ et 8 , alors que la solubilité des concentrés de lactosérum fromager variait de 75 à $90 \%$ sur la même fourchette de $\mathrm{pH}$. La structure native de la $\beta$-lactoglobuline, évaluée par la position du groupement SH libre, était fortement altérée dans le concentré de lactosérum fromager. L'altération structurale de la $\beta$-lactoglobuline était moins importante dans l'isolat de microfiltrat de lait, mais toutefois significative. Les propriétés thermogélifiantes de l'isolat de microfiltrat de lait étaient supérieures à celles du concentré de lactosérum fromager. L'isolat de microfiltrat de lait formait des 
mousses fermes et stables alors que le concentré de lactosérum fromager refusait de mousser. Les propriétés gélifiantes et moussantes étaient sensibles à l'environnement ionique et modulées par la combinaison du $\mathrm{pH}$ et de la disponibilité du calcium dans le milieu. La réduction de la teneur en calcium de l'isolat protéique, par l'utilisation d'une solution saline comme solvant de diafiltration, n'a cependant eu qu'une influence mineure sur ses propriétés fonctionnelles.

\section{microfiltration / protéine du lactosérum / ultrafiltration / gélification thermique / propriété moussante}

\section{INTRODUCTION}

Recent developments in membrane technology led to commercial uses of crossflow microfiltration in dairy industry. Microfiltration is used to remove bacterial contaminants and suspended materials from milk or whey (Trouvé et al, 1991; Gésan et al, 1993; Mucchetti and Taglietti, 1993). Microfiltration makes possible also the selective concentration of native casein micelles (Fauquant et al, 1988). This concentrate is heat stable and well suited for cheese milk standardization and enrichment (Pierre et al, 1992). Furthermore, casein concentration through microfiltration produces a high value milk microfiltrate.

Milk microfiltration permeate is obtained from non-fermented milk, which brings important differences when compared to cheese whey. Milk microfiltrate is almost free from bacteria and bacteriophages (Gautier et al, 1994). It requires then very mild heat treatment to ensure salubrity and to be used as in the formulation of cultured products. Milk microfiltrate is also free from degradation products related to starter culture and milk coagulation enzyme activities. Since milk is not acidified before whey separation, the mineral equilibrium is not altered and remains similar to that of milk. Compared to cheese whey, lower amounts of calcium and phosphorus and almost no organic acids are expected. Finally, milk microfiltrate is expected to contain only traces of fat. Clarification treatments to remove lipids are not required to produce ingredients with good functional properties.
The purpose of this study was to concentrate protein from milk microfiltration permeate and cheese whey and to compare their functional properties.

\section{MATERIALS AND METHODS}

\section{Preparation of protein concentrates from milk microfiltrate and cheese whey}

Fresh raw milk was skimmed and microfiltered, with the MFS-7 Alfa-Laval equipment (AlfaLaval, Lund, Sweden) operated at $50^{\circ} \mathrm{C}$. An initial filtration using a 1 P 19 Membralox (SCT, Tarbes, France) $1.4 \mu \mathrm{m}$ pore size cartridge ( $0.85 \mathrm{~m}$ length; internal diameter of channels: $4 \mathrm{~mm}$; area $0.2 \mathrm{~m}^{2}$ ) was performed according to Trouvé et al (1991), to reduce bacterial contamination. A second filtration using a $0.1 \mu \mathrm{m}$ pore size cartridge was performed according to Pierre et al (1992), to concentrate native phosphocaseinate. The permeate of this second microfiltration, containing whey proteins, lactose and minerals, was used as starting material. A $120 \mathrm{~kg}$ mass of milk microfiltrate was batch-concentrated up to weight concentration factor 16 with the UFS-1 Alfa-Laval equipment fitted with a PM 10 polysulfone hollow fibre (internal diameter of fibres: $1.5 \mathrm{~mm}$; area $1.3 \mathrm{~m}^{2}$ ) ultrafiltration cartridge (Romicon Corp, Woburn, MA, USA). Temperature during concentration was maintained at $50^{\circ} \mathrm{C}$. Inlet and outlet pressure were maintained at 1.8 and 0.6 bar, respectively. Permeate flux was measured and permeate samples were withdrawn at weight concentration factors (CF) 1, 1.5, 2, 3, 5, 8, 12, and 16. Following concentration, the retentate $(7.5 \mathrm{~kg})$ was diafiltered by the addition of $37.5 \mathrm{~kg}$ of deionized water in continuous mode, which corresponded to a final mass dilution rate $(\alpha=\mathrm{kg}$ added water $/ \mathrm{kg}$ retentate) of 5 . Permeate flux was measured and permeate samples were with- 
drawn at dilution rates $(\alpha) 0,1,2,3,4$ and 5 . The retentate was then freeze-dried and stored at $-20^{\circ} \mathrm{C}$ until further analysis. A second concentrate was produced by the same process but during diafiltration, sodium chloride solution $(0.3 \% \mathrm{w} / \mathrm{w})$ was used instead of water up to $\alpha=3$, in order to further reduce the calcium content of the retentate. Excess sodium was removed using deionized water from $\alpha=3$ to $\alpha=5$. A third concentrate was obtained from pasteurized Cheddar cheese whey (from a local cheese factory). The same process was applied to cheese whey, with the use of sodium chloride solution in the early stages of diafiltration. Each protein concentrate was produced three times with starting material from independent batches (raw milks or cheese wheys).

\section{Composition analysis}

Ultrafiltration permeate samples were analyzed for total nitrogen (Kjeldahl), ashes $\left(5 \mathrm{~h}, 550^{\circ} \mathrm{C}\right)$ and calcium (adapted from Pearce, 1977). In addition, freeze-dried protein concentrates were analyzed for non-casein nitrogen (NCN) and non-protein nitrogen (NPN) (Rowland, 1938). The main protein fractions were analyzed by reverse phase HPLC using C4 bonded silica column (Vydac 214TP, The Separations Group, Hesperia, CA, USA) according to Kim et al (1987). Total lipids were determined from methanol/chloroform (2:1 v/v) extraction according to Pierre et al (1994). Lactose was spectrophotometrically measured (Dubois et al, 1956) and the minerals $(\mathrm{Ca}, \mathrm{Mg}, \mathrm{Na}, \mathrm{K})$ were detected using inductively coupled plasma spectrometry (ICP spectrometer model 3510, Applied Research Laboratories, Sunland, CA, USA).

\section{Retention coefficients}

The averaged retention coefficient of solutes during concentration was calculated from changes in retentate composition, according to Glover (1985):

$$
\mathrm{C}=\mathrm{Co} . \mathrm{CF}^{\mathrm{R}}
$$

where $\mathrm{Co}$ is the initial concentration of solute, C, the solute concentration at concentration factor CF and $R$, the averaged retention coefficient. The $R$ value was the slope of $\log C / C o$ vs Log CF and was obtained through linear regression analysis.
Average retention coefficient during diafiltration was also determined from changes in retentate composition (Glover, 1985).

$$
\mathrm{Co}=\mathrm{C} \cdot \mathrm{e}^{(1-\mathrm{A}) \cdot \alpha}
$$

where $\alpha$ is the dilution rate. The $R$ value was obtained from the slope (1-R) of In Co/C vs $\alpha$ and was obtained through linear regression analysis.

\section{Free SH groups determination}

Total free SH groups were determined spectrophotometrically from reaction with DTNB. ACcording to Shimada and Cheftel (1989), the SH group in the native state of $\beta$-lactoglobulin (position 119/121) reacts more slowly with DTNB in presence of SDS than other $\mathrm{SH}$ groups resulting from $\mathrm{SH} / \mathrm{S}-\mathrm{S}$ interchange reactions. The kinetic data of the reaction (reacting $\mathrm{SH}$ groups vs time) were then fitted to a double exponential equation. The first exponential represented the contribution from the slow reacting SH groups and the second, the contribution from the fast reacting $\mathrm{SH}$ groups:

$$
\mathrm{SH}_{\mathrm{t}}=\mathrm{SH}_{\mathrm{s}} \cdot\left(1-\mathrm{e}^{-.0034 t}\right)+\mathrm{SH}_{\mathrm{F}} \cdot\left(1-\mathrm{e}^{-0.04121}\right)
$$

where $\mathrm{SH}_{4}$ is the concentration of $\mathrm{SH}$ group reacting with DTNB at time $\mathrm{t}, \mathrm{SH}_{\mathrm{s}}$, the concentration of slow reacting $\mathrm{SH}$ groups in the protein sample and, $\mathrm{SH}_{F}$, the concentration of fast reacting $\mathrm{SH}$ groups in the protein sample. Rate constant of the first exponential $(-0.0034)$ was obtained from kinetic data of whey protein isolated from acidified fresh raw milk and fitted to a single exponential model. $\beta$-Lactoglobulin in fresh raw milk was assumed to contain exclusively slow reacting $\mathrm{SH}$ groups. The rate constant for the second exponential $(-0.0461)$ was obtained from kinetic data of denatured whey protein isolate $\left(1 \%\right.$ solution heated at $90{ }^{\circ} \mathrm{C}$ for $\left.20 \mathrm{~min}\right)$, fitted to a double exponential with -0.0034 used as the rate constant of the first exponential. SH group concentrations are reported as $\mu \mathrm{mol}$ per $g$ of $\beta$-lactoglobulin (according to the protein composition (table I), the theoretical contribution of BSA to the free SH groups content of the isolates was less than $1 \%$ and was neglected in calculations).

\section{Solubility of protein concentrates}

Protein solubility was determined from whey protein concentrates suspended in deionized water. 
Table I. Composition of whey protein concentrates on dry matter basis $\left(\mathrm{g} \mathrm{kg}^{-1}\right)$.

Composition des concentrés protéiques sur base sèche $\left(\mathrm{g} \mathrm{kg}^{-1}\right)$.

\begin{tabular}{lrrr}
\hline Concentrate from & $M M$ & $M M-L C^{\star}$ & $C W$ \\
\hline Protein & $958^{\mathrm{a}^{* *}}$ & $962^{\mathrm{a}}$ & \multicolumn{1}{c}{779} \\
NCN $(\times 6.38)$ & $895^{\mathrm{a}}$ & $890^{\mathrm{a}}$ & 660 \\
$\beta$-lactoglobulin & $794^{\mathrm{a}}$ & $788^{\mathrm{a}}$ & 591 \\
$\alpha$-lactalbumin & $71^{\mathrm{a}}$ & $78^{\mathrm{a}}$ & $54^{\mathrm{a}}$ \\
BSA & $30^{\mathrm{a}}$ & $24^{\mathrm{a}}$ & $14^{\mathrm{a}}$ \\
NPN $(\times 6.38)$ & $9^{\mathrm{a}}$ & $8^{\mathrm{a}}$ & 38 \\
Lipids & $2^{\mathrm{a}}$ & $2^{\mathrm{a}}$ & 155 \\
& & & \\
Lactose & $13.4^{\mathrm{a}}$ & $14.2^{\mathrm{a}}$ & 22.2 \\
& & & \\
Ash & $18^{\mathrm{a}}$ & $20^{\mathrm{a}}$ & $23^{\mathrm{a}}$ \\
Ca & 3.3 & $1.0^{\mathrm{a}}$ & $1.1^{\mathrm{a}}$ \\
$\mathrm{Mg}$ & 0.36 & $0.09^{\mathrm{a}}$ & $0.10^{\mathrm{a}}$ \\
$\mathrm{Na}$ & $0.7^{\mathrm{a}}$ & $4.4^{\mathrm{a}}$ & $3.0^{\mathrm{a}}$ \\
$\mathrm{K}$ & 1.5 & $0.4^{\mathrm{a}}$ & $0.2^{\mathrm{a}}$ \\
$\mathrm{P}$ & $0.5^{\mathrm{a}}$ & $0.3^{\mathrm{a}}$ & $0.5^{\mathrm{a}}$
\end{tabular}

"Low calcium (diafiltered with $\mathrm{NaCl}$ solution). Faible teneur en calcium (diafiltré avec une solution de $\mathrm{NaCl}$ ).

*"Means in a same row, followed by the same letter are not significantly different $(\alpha=0.05)$.

Les moyennes d'une même ligne suivies de la même lettre ne sont pas significativement différentes $(\alpha=0,05)$.

The effect of $\mathrm{pH}$ and added calcium on the solubility were tested through a $11 \times 4$ completely randomized design. The $\mathrm{pH}$ of the solution was adjusted (between 3 and 8 with $1 \mathrm{~mol} \mathrm{L-1} \mathrm{HCl}$ or $1 \mathrm{~mol} \mathrm{~L}^{-1} \mathrm{NaOH}$ ) and $\mathrm{CaCl}_{2}$ was added at four different levels $\left(0,5,10\right.$ and $\left.15 \mathrm{mmol} \mathrm{L}^{-1}\right)$. Final protein concentration was adjusted to $10 \mathrm{~g} \mathrm{~L}^{-1}$. Protein dispersions were centrifuged at $20000 \mathrm{~g}$ for $15 \mathrm{~min}$. Solubility was obtained from the absorbance ratio between the supernatant and the dispersion before centrifugation. Absorbance was measured at $280 \mathrm{~nm}$ on a sample aliquot diluted $1: 10(\mathrm{v} / \mathrm{v})$ in dissociating buffer ( $50 \mathrm{mmol} \mathrm{L}^{-1}$ EDTA; $8 \mathrm{~mol} \mathrm{~L}^{-1}$ urea; $\mathrm{pH} 10$ ).

\section{Gelling properties of protein concentrates}

Whey protein concentrates were dispersed in deionized water. The effect of $\mathrm{pH}(4.0,6.0$ and 8.0) and added calcium $\left(0,5,10\right.$ and $\left.15 \mathrm{mmol} \mathrm{L}^{-1}\right)$ on gelling properties were tested through a split plot factorial design, with the whey concentrates and the $\mathrm{pH}$ in the main plot and the level of added calcium in the subplot. Final protein concentration was adjusted to $75 \mathrm{~g} \mathrm{~L}-1$. A 2-ml sample of protein solution was placed in a $11-\mathrm{mm}$ internal diameter test tube and heated at $90{ }^{\circ} \mathrm{C}$ for $30 \mathrm{~min}$. Gels were cooled in an ice bath for $5 \mathrm{~min}$ and allowed to stand $2 \mathrm{~h}$ at $22 \pm 1{ }^{\circ} \mathrm{C}$ before analysis. Strain-deformation curves were monitored at the same temperature using a texture analyzer (model TA-XT2, Texture Technologies Corp, Scarsdale, NY, USA). The probe was a flat cylinder (6-mm diameter) which penetrated the gel at a speed of $0.8 \mathrm{~mm} \mathrm{~s}^{-1}$. Maximal deformation was set to $15 \mathrm{~mm}$. Gel strength was associated with the force required to fracture the gel (maximum on strain-deformation curve). Broken gels were then centrifuged $(2500 \mathrm{rpm}$, $15 \mathrm{~min}$ ), and syneresis index was calculated from the volume proportion of free serum. All gels were prepared and analyzed in triplicates.

\section{Foaming properties of protein concentrates}

Whey protein concentrates were dispersed in deionized water. The effect of $\mathrm{pH}(4.0,6.0$ and 8.0$)$ and added calcium $\left(0,5,10\right.$ and $\left.15 \mathrm{mmoL} \mathrm{L}^{-1}\right)$ on foaming properties were tested through a split plot factorial design, with the whey concentrates and the $\mathrm{pH}$ in the main plot and the level of added calcium in the subplot. Final protein concentration was adjusted to $50 \mathrm{~g} \mathrm{~L}^{-1}$. A $100-\mathrm{mL}$ sample was whipped at $22{ }^{\circ} \mathrm{C} \pm 1{ }^{\circ} \mathrm{C}$ with an electrical mixer (model Mixmaster, Sunbeam Corporation, Toronto, Canada) operating at maximum speed for $5 \mathrm{~min}$. Foam expansion factor was calculated from the density ratio between the solution and the foam. Foam firmness was measured with a Brookfield viscometer (Model DVII) mounted on a Helipath support and fitted with a ' $T$ 'type spindle. Spindle rotational speed was set to $12 \mathrm{rpm}$, while vertical displacement was fixed at $2.5 \mathrm{~cm} \mathrm{~min}^{-1}$. Apparent viscosity was measured after $1-\mathrm{cm}$ penetration. Foam drainage stability was defined as the time required to drain half the foam weight. For that purpose, a $50-\mathrm{mL}$ funnel ('combitip' from Brinkmann, Rexdale, Canada) was filled with freshly prepared foam and placed over a balance. The balance was connected to a computer which collected weight data of drained liquid as a function of time. 


\section{Statistical analyses}

Analysis of variance was used to determine if the factors and their interactions had a significant effect on the measured properties (SAS Institute Inc, Cary, NC, USA). Statistical analyses were performed at an $\alpha=0.05$. Composition and physicochemical properties of whey protein concentrates were compared through multiple comparisons of least square means at controlled $\alpha$ level of 0.05 . Contrast analyses were used to compare the gelling and foaming behaviours of whey protein concentrates. Error bars on graphs represent the standard error obtained from the statistical models.

\section{RESULTS AND DISCUSSION}

\section{Concentration of whey protein}

Cheese whey and milk microfiltrate were batch-concentrated up to CF 16. As a consequence of membrane fouling, the permeate flux permeate rapidly decreased with increasing CF (fig 1a). In the early stages of concentration, flux declined faster with milk microfiltrate than with cheese whey $(P=0.0001)$. At CF greater than 10 , permeate fluxes values were similar and averaged $18 \mathrm{~L} \mathrm{~h}^{-1} \mathrm{~m}^{-2}$. Considering the generally accepted relationship between ultrafiltration flux decline and residual lipids in whey (de Wit and de Boer, 1975; Merin and Gordin, 1983; Piot et al, 1984; Daufin et al, 1992), lower flux observed during concentration of milk microfiltrate was not expected. However, lipid content is not the only composition factor controlling permeate flux. Calcium phosphate precipitation during concentration of dairy fluids is responsible for severe flux decline (Merin and Cheryan, 1980; Glover, 1985). The $\mathrm{pH}$ of milk microfiltrate was slightly higher than that of cheese whey (6.6 vs 6.2 ), which could have promoted mineral precipitation. In order to reduce mineral fouling, it would be appropriate to slightly reduce the $\mathrm{pH}$ of milk microfiltrate or to operate the ultrafiltration unit at a temperature lower than the temperature used during milk microfiltration.
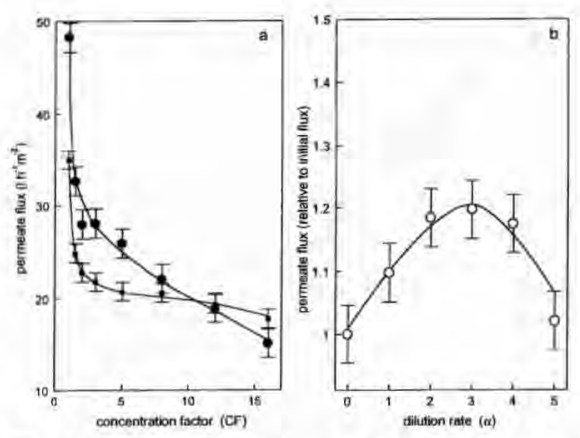

Fig 1. Permeate flux during (a), batch-concentration (-, milk microfiltrate; $\mathbf{n}$, cheese whey) and (b), diafiltration of whey.

Flux de perméation pendant (a), la concentration en batch (- microfiltrat de lait; $\mathbf{n}$, lactosérum de fromage) et (b), la diafiltration du lactosérum.

The average retention coefficients $(R)$ for nitrogen compounds during concentration of milk microfiltrate and cheese whey were not significantly different $(P=0.4221)$ and averaged 0.83 (data not shown). Calcium retention during concentration was slightly higher for cheese whey $(R=0.18)$ than for milk microfiltrate $(R=0.16)(P=0.0401)$. This difference was attributed to the portion of non-permeable calcium which increased with thermal treatments (pasteurization) of cheese milk and whey (Brulé and Fauquant, 1981).

\section{Diafiltration of whey protein}

After concentration ( $C F=16$ ), cheese whey $(\mathrm{CW})$ and milk microfiltrate (MM) were diafiltered in continuous mode up to $\alpha=5$. The permeate flux was not affected either by the type of whey or the diafiltration solvent (water vs $\mathrm{NaCl}$ solution) ( $P=0.3658$ ). However, the permeate flux showed variations associated with dilution rate $(\alpha)(P=0.0213)$ (fig 1 b). From $\alpha=0$ to $\alpha=3$, the flux gradually increased up to $120 \%$ of its initial value. Flux increase was attributed to the viscosity decrease of UFpermeate resulting from the elimination of lactose (Peri et al, 1973). Further diafiltra- 


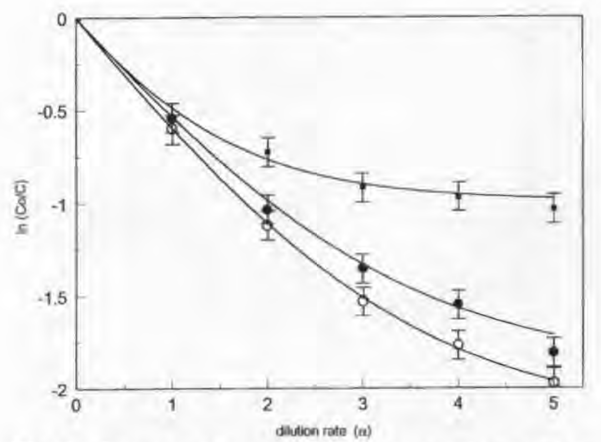

Fig 2. Change in calcium concentration during diafiltration of whey concentrate. $\mathbf{n}, \mathrm{MM}$-concentrate diafiltered with deionized water; $O$, MMconcentrate diafiltered with $\mathrm{NaCl}$ solution up to $\alpha=3$, followed with deionized water; - , CWconcentrate diafiltered with $\mathrm{NaCl}$ solution up to $\alpha=3$, followed with deionized water.

Évolution de la concentration en calcium pendant la diafiltration du concentré de lactosérum.

口, concentré de microfiltrat de lait diafiltré avec l'eau déionisée; 0 , concentré de microfiltrat de lait diafiltré avec une solution de $\mathrm{NaCl}$ jusqu'à $\alpha=3$, puis avec l'eau déionisée ; , concentré de lactosérum de fromage diafiltré avec une solution de $\mathrm{NaCl}$ jusqu'à $\alpha=3$, puis avec l'eau déionisée.

tion reversed the trend, with permeate flux almost back to its initial value at $\alpha=5$, suggesting further fouling of the UF membrane.

Average retention for nitrogen compounds was not affected either by the type of whey or the diafiltration solvent $(P=0.6241)$ with a coefficient of 0.95 . Calcium retention coefficient increased during diafiltration as evidenced by the non-linear relationship between $\ln (\mathrm{Co} / \mathrm{C})$ vs $\alpha$ curves (fig 2). This deviation from linearity was attributed to the portion of non-permeable calcium. Non-permeable calcium, expressed on a protein basis averaged $3.4 \mathrm{mg} \mathrm{g}^{-1}$ in milk microfiltrate protein isolate. It was reduced by $70 \%$ when sodium chloride was used in the early stages of diafiltration. Use of sodium chloride during diafiltration of cheese whey led to a similar result.

\section{Composition of whey protein isolates}

Compositions of MM-isolates and CWconcentrate are presented in table I. Protein concentration of MM-isolates averaged $96 \%$ on a dry matter basis. The CW-concentrate showed lower protein content $(77.9 \%)$ due to the significant amount of lipids concentrated with proteins during ultrafiltration. In MM-isolates, the $\mathrm{pH} 4.6$-insoluble fraction averaged $7.0 \%$ of total protein. Pierre et al (1992) found a similar proportion in milk microfiltration permeate $(6.4 \%)$ and associated it to the presence of caseins. The $\mathrm{pH} 4.6$-insoluble protein fraction in CW-concentrate was higher $(15.3 \%)$. Denaturation of whey proteins, induced by pasteurization steps during cheese making would explain the difference. The proportion of the various whey proteins was altered by the concentration process. The weight ratio between $\beta$-lactoglobulin and a-lactalbumin, which is slightly higher than $4: 1$ in milk serum (Marshall, 1982), increased to at least $10: 1$ in ultrafiltration concentrate. Polymeric membranes, such as those used in the present study are generally characterized by a diffuse cut-off and allow slight protein permeation according to molecular size (Cheryan, 1986). A lower extent of proteolysis in milk microfiltrate compared to cheese whey would explain the lower NPN content in MM-isolates. Lipid content of MMisolates was much lower than in $\mathrm{CW}$-concentrate. The mineral composition of MM-isolate was modified by the use of sodium chloride instead of water in the early stages of diafiltration: $\mathrm{Ca}, \mathrm{Mg}$ and $\mathrm{K}$ concentrations were reduced by about $70 \%$, while sodium increased from $0.7 \mathrm{~g} \mathrm{~kg}^{-1}$ to $4.4 \mathrm{~g} \mathrm{~kg}^{-1}$.

\section{Protein denaturation}

The kinetics of the reaction between free $\mathrm{SH}$ groups and DTNB reagent was used to determine the extent of SH/S-S interchange of $\beta$-lactoglobulin (table II). The 
Table II. SH groups characteristics in whey protein concentrates ( $\mu \mathrm{mol} \mathrm{g}^{-1} \beta$-lactoglobulin). Caractéristiques des groupements SH dans les concentrés protéiques ( $\mu \mathrm{mol} \mathrm{g}^{-1} \beta$-lactoglobuline).

SHinterchanged $\mathrm{SH}_{\text {native }} \mathrm{SH}_{\text {tot }}$

\begin{tabular}{lccc}
\hline MM-isolate & $9.6^{\mathrm{a}^{*}}$ & $28.6^{\mathrm{a}, \mathrm{b}}$ & $38.2^{\mathrm{a}}$ \\
MM-isolate LC & $10.1^{\mathrm{a}}$ & $28.7 \mathrm{a}$ & $38.8^{\mathrm{a}}$ \\
CW-concentrate & $23.3^{\mathrm{a}}$ & 6.6 & 29.9 \\
\hline
\end{tabular}

"Means in a same row, followed by the same letter are not significantly different $(\alpha=0.05)$. " filtered with $\mathrm{NaCl}$ solution).

'Les moyennes d'une même ligne suivies de la même lettre ne sont pas significativement différentes $(\alpha=0,05)$. ${ }^{* *}$ Faible teneur en calcium (diafiltré avec une solution de $\mathrm{NaCl}$ ).

slow-reacting $\mathrm{SH}$ group content of $\beta$-lactoglobulin in $\mathrm{MM}$-isolates was close to $29 \mu \mathrm{mol} \mathrm{g}^{-1}$ and represented $75 \%$ of total $\mathrm{SH}$ groups. The concentration process induced significant structure alteration through SH/S-S interchange reactions resulting in $25 \%$ decrease of native $\beta$-lactoglobulin content. In the present study, whey was batch-concentrated. It was then submitted to pumping and was maintained at $50^{\circ} \mathrm{C}$ for a long period of time. Such conditions have been shown to induce partial protein unfolding (Harris et al, 1989). In order to preserve the native structure of $\beta$ lactoglobulin, it would be appropriate to use a system configuration with shorter residence time and reduce filtration temperature, $\beta$-Lactoglobulin from $\mathrm{CW}$-concentrate showed a lower level of slow reacting $\mathrm{SH}$ groups which represented $22 \%$ of total $\mathrm{SH}$ groups. This proportion of $\mathrm{SH}$ group in native position is close to the expected equilibrium value $(20 \%)$ assuming an extensive and random interchange reaction.

According to its molecular mass (18 362 $\mathrm{Da}$; Swaisgood, 1982) the total free $\mathrm{SH}$ group content of native $\beta$-lactoglobulin is
$54.5 \mu \mathrm{mol} \mathrm{g}^{-1}$. A lower free $\mathrm{SH}$ group content reflects the formation of intermolecular disulphide bonds or other oxidation products (Donovan and Mulvihill, 1987). In table II, it can be seen that the total SH group content of $\beta$-lactoglobulin in MM-isolates averaged $38.5 \mu \mathrm{mol} \mathrm{g}{ }^{-1}$, corresponding to $29.4 \%$ of the original $\mathrm{SH}$ being oxidized. Batch ultrafiltration, performed at $50{ }^{\circ} \mathrm{C}$, was likely to induce significant alteration of whey protein structure. A lower $\mathrm{SH}$ content of $\beta$-lactoglobulin was found in CW-concentrate, where $45.1 \%$ of the original content of $\mathrm{SH}$ groups had been oxidized.

\section{Solubility of whey protein isolates}

Solubility of protein isolates was measured at various pHs. Solubility was not influenced by the addition of calcium $(P=0.2601)$ and results presented in figure 3 are the averages of solubility measured at the four calcium levels. The solubility of MM-isolates averaged $97 \%$ at $\mathrm{pH}$ values below 4.5 and higher than 5.5. A slight decrease was observed at the isoelectric point of $\beta$ lactoglobulin (IP = 5.3). The $\mathrm{CW}$-concentrate showed lower solubility than MM-iso-

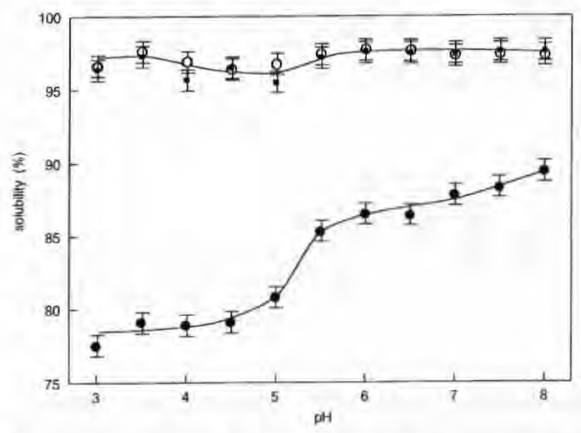

Fig 3. Solubility of whey protein concentrates. E, MM-Isolate; O, low calcium MM-isolate; -, CW-concentrate.

Solubilité des concentrés protéiques de lactosérum. $\mathbf{\square}$, isolat de microfiltrat de lait ; $\bigcirc$, isolat de microfiltrat de lait faible en calcium ; , concentré protéique de lactosérum de fromage. 
lates at any $\mathrm{pH}$ tested. Furthermore, solubility in the low $\mathrm{pH}$ portion of the profile did not improve compared to the solubility at the isoelectric point of $\beta$-lactoglobulin. The solubility profile suggests that proteins in cheese whey suffered from severe treatment probably associated with the cheese making practices or whey pasteurization conditions.

\section{Gelling properties}

Thermal gels were produced from whey protein solutions. The effects of $\mathrm{pH}$ adjustment and calcium addition on gel properties were tested. The gel strength was significantly affected by both variables and the type of whey protein concentrate $(P=0.0001)$ (fig 4$)$. Cheese whey concentrate produced very soft gels with maximum gel strength values around $50 \mathrm{~g}$ under optimum conditions ( $\mathrm{pH} 4.0)$. Presence of fat in the concentrate (Morr et al, 1993) and evidence of severe protein denaturation (Mangino et al, 1987) could explain the poor gelling performance.

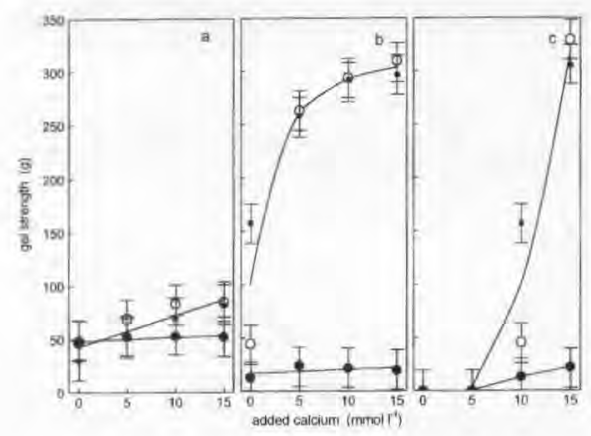

Fig 4. Effect of $\mathrm{pH}$ and added calcium on whey protein gel strength. a, $\mathrm{pH} 4 ; \mathrm{b}, \mathrm{pH} 6 ; \mathrm{c}, \mathrm{pH} 8$;

n, MM-isolate; $\bigcirc$, low calcium MM-isolate; - CW-concentrate.

Effet du pH et de l'ajout de calcium sur la fermeté des gels protéiques. a, $\mathrm{pH} 4 ; b, \mathrm{pH} 6 ; c, \mathrm{pH} 8$; 日, Isolat de microfiltrat de lait ; $O$, isolat de microfiltrat de lait faible en calcium ;, concentré protéique de lactosérum de fromage.
Protein isolate from milk microfiltrate gelled at the three $\mathrm{pHs}$ tested. From contrast analysis, it was shown that the use of sodium chloride during the early stages of diafiltration did not influence the gel strength $(P=0.8524)$. It seems that calcium complexes did not affect gelation. However, the addition of ionic calcium increased the gel strength and this effect was more important as the $\mathrm{pH}$ increased. Calcium ions promoted protein-protein interactions through cross-linking negatively charged residues. Increasing $\mathrm{pH}$ increased the proportion of residues involved in calcium bridges. It has been shown that the strength of thermal gels from clarified whey protein concentrates increased with $\mathrm{pH}$ increasing from 5 to 9 (Gault et al, 1990). At low $\mathrm{pH}$, the gel strength was essentially explained by non-specific interactions between protein molecules, while calcium bridges and disulphide bond formation explained gel strength at higher $\mathrm{pH}$ (Schmidt et al, 1979). A combination of high $\mathrm{pH}$ and high ionic calcium content produced the strongest gels.

Whey protein gels were centrifuged and syneresis was monitored (fig 5). All the variables studied $(\mathrm{pH}$, calcium, protein source) and their statistical interactions had significant effects on gel syneresis $(P=0.0001)$. As a general trend, gels from MM-isolates showed lower levels of syneresis than gels from $\mathrm{CW}$-concentrate. Again, the use of sodium chloride during the early steps of diafiltration did not affect syneresis $(P=0.1500)$. Minimum syneresis was observed on gels obtained at $\mathrm{pH}$ 4.0. The aggregated protein matrix formed at this $\mathrm{pH}$ was soft (fig 4) and highly hydrated. Addition of calcium for gels produced at $\mathrm{pH} 8.0$ decreased syneresis. Under alkaline conditions, calcium ions contributed to the formation of strong gel matrix (fig 4) which resisted deformation upon centrifugation. Under these conditions, low syneresis was related to the gel matrix mechanical properties. 


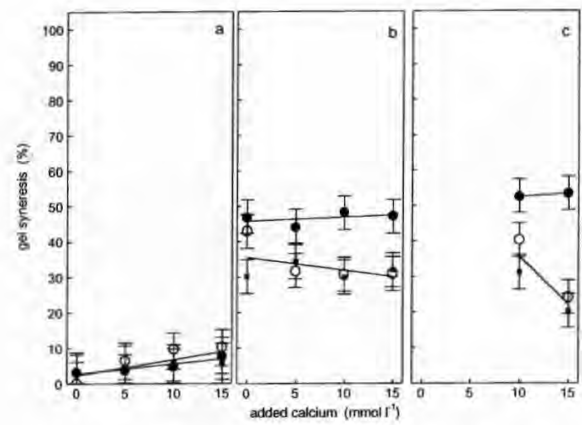

Fig 5. Effect of $\mathrm{pH}$ and added calcium on whey protein gel syneresis. a, $\mathrm{pH} 4$; b, $\mathrm{pH} 6 ; \mathrm{c}, \mathrm{pH} 8$; D. MM-isolate; $O$, low calcium MM-isolate; CW-concentrate.

Effet du pH et de l'ajout de calcium sur la synérèse des gels protéiques. $a, \mathrm{pH}_{4} ; b, \mathrm{pH} 6 ; c, \mathrm{pH} 8$; a, isolat de microfiltrat de lait ; 0 , isolat de microfiltrat de lait faible en calcium ; , concentré protéique de lactosérum de fromage.

\section{Foaming properties}

Foaming properties of whey protein solutions were determined at various $\mathrm{pHs}$ and different levels of added calcium. Cheese whey protein concentrate did not foam at all over the entire range of conditions tested. The lipid content of CW-concentrate (table I) was responsible for deficient foaming behaviour (Maubois, 1988; Joseph and Mangino, 1988). Protein isolates from milk microfiltrate showed much better foaming properties (fig 6). Foam expansion was slightly lower for low calcium isolate (use of sodium chloride in the early steps of diafiltration) $(P=0.0069)$, and the difference remained constant over the range of conditions tested. The addition of calcium to the protein solution had no significanteffect on foam expansion ( $P=0.2354)$. It suggests that transport and spreading of protein molecules at the air-water interface during the foaming process are not influenced by calcium concentration. However, foam expansion of MM-isolates

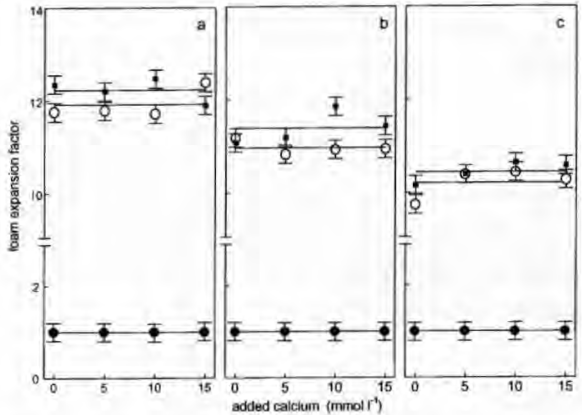

Fig 6. Effect of $\mathrm{pH}$ and added calcium on whey protein foam expansion factor. a, $\mathrm{pH} 4 ; \mathrm{b}, \mathrm{pH} 6$; c, $\mathrm{pH} 8$; $\mathbf{E}, \mathrm{MM}$-isolate; $\mathrm{O}$, low calcium MM-isolate; $\mathrm{CW}$-concentrate.

Effet du pH et de l'ajout de calcium sur le facteur d'expansion des mousses protéiques. a, $\mathrm{pH} 4$; $b, \mathrm{pH} 6 ; c, p H 8 ; \mathbf{0}$, isolat de microfiltrat de lait; $\mathrm{O}$, isolat de microfiltrat de lait faible en calcium ; - concentré protéique de lactosérum de fromage.

was influenced by the $\mathrm{pH}$ of the solution. As $\mathrm{pH}$ increased, the foam expansion factor decreased. Alkaline conditions increased the net negative charge of protein molecules. Transport to the air-water interface was then slowed down by increased electrostatic repulsion between proteins in solution and proteins already adsorbed at the interface (Kinsella and Whitehead, 1989). Increased charge of protein molecules also promoted intra-molecular repulsions and spreading at the interface. These two factors were associated with the formation of thin and unstable protein films, susceptible to collapse during whipping.

Addition of calcium, and $\mathrm{pH}$ adjustment had various effects on foam firmness (fig 7). Increasing both calcium concentration and $\mathrm{pH}$ increased the firmness of foams from MM-isolates. These conditions promoted the formation of calcium bridges leading to a more rigid membrane at the air-water interface. It was noticed that the use of sodium chloride during diafiltration (low calcium isolate) reduced 


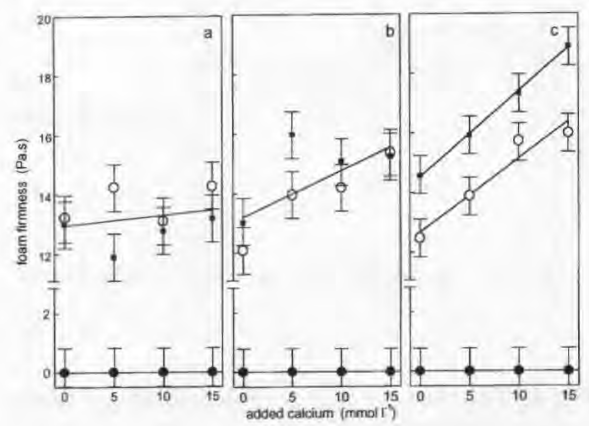

Fig 7. Effect of $\mathrm{pH}$ and added calcium on whey protein foam firmness. a, $\mathrm{pH} 4 ; \mathrm{b}, \mathrm{pH} 6 ; \mathrm{c}, \mathrm{pH}$ 8;

a, MM-isolate; $\bigcirc$, low calcium MM-isolate; - CW-concentrate.

Effet du pH et de l'ajout de calcium sur la fermeté des mousses protéiques. $a, \mathrm{pH} 4 ; b, \mathrm{pH} 6 ; c$, $\mathrm{pH} 8$; $\mathbf{a}$, isolat de microfiltrat de lait ; $\mathrm{O}$, isolat de microfiltrat de lait faible en calcium ; $\bullet$ concentré protéique de lactosérum de fromage.

the firmness of foams produced at $\mathrm{pH}$ 8.0. Higher level of monovalent cations in the MM-isolate diafiltered with saline solution (table I) could have masked some residues which otherwise would have participated in calcium bridges. From these results, it seems that foam firmness is controlled by the combined effect of $\mathrm{pH}$, monovalent cations and available ionic calcium on the electrostatic repulsions and calcium bridge formation between protein molecules at the air-water interface.

Foam stability results reflected also the combined effect of the variables under study on foaming properties (fig 8). At low $\mathrm{pH}$, foam was stable and not affected by the addition of calcium. As $\mathrm{pH}$ increased, foam stability tended to decrease, but was improved by the addition of calcium. There was no significant effect associated with the use of sodium chloride during the early stage of diafiltration $(P=0.4804)$.

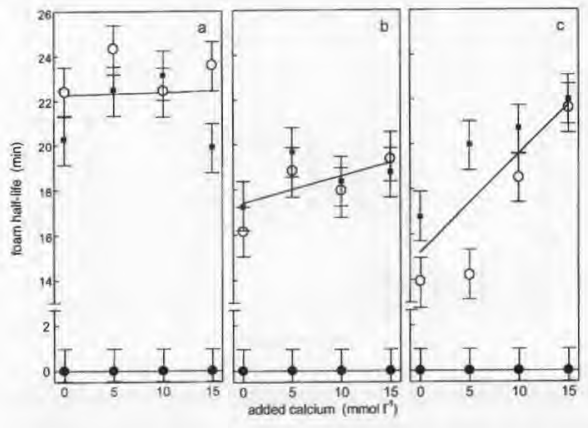

Fig 8. Effect of $\mathrm{pH}$ and added calcium on whey protein foam stability. a, $\mathrm{pH} 4 ; \mathrm{b}, \mathrm{pH} 6 ; \mathrm{c}, \mathrm{pH} 8$; 日, MM-isolate; $\mathrm{O}$, low calcium MM-isolate; -, CW-concentrate.

Effet du pH et de l'ajout de calcium sur la stabilité des mousses protéiques. $a, p H 4 ; b, p H 6 ; c$, $\mathrm{pH} 8$; $\mathbf{\square}$, isolat de microfiltrat de lait ; $\mathrm{O}$, isolat de microfiltrat de lait faible en calcium; concentré protéique de lactosérum de fromage.

\section{CONCLUSION}

Concentration of proteins from milk microfiltrate led to a high value protein isolate with improved solubility, gelling and foaming properties (compared to cheese whey). However, it has been shown that the structure of $\beta$-lactoglobulin had been altered by the concentration conditions used in the present study. To further improve the quality of the isolate, the filtration conditions should be revised in order to reduce protein structure alteration.

The functional properties of the isolate were strongly dependent on the ionic environment ( $\mathrm{pH}$, calcium content). In order to develop the desired properties, the quality of the ionic environment is as important as the quality of the protein ingredient. The balance between $\mathrm{pH}$ and calcium content should be controlled to ensure optimal behaviour of whey protein isolates in complex food systems. 


\section{ACKNOWLEDGMENTS}

The authors wish to thank S Bastrash, HJ Giroux and N Raymond for technical assistance.

\section{REFERENCES}

Brulé G, Fauquant J (1981) Mineral balance in skim-milk and milk retentate: effect of physicochemical characteristics of the aqueous phase. J Dairy Res 48 , 91-97

Cheryan M (1986) Ultrafiltration Handbook. Technomic publishing $\mathrm{co}$, Landcaster, USA

Daufin G, Michel F, Merin U (1992) Study of defatted whey protein concentrates (WPC) withdrawn from an industrial plant. Lait 72, 185-199

de Wit JN, de Boer R (1975) Ultrafiltration of cheese whey and some functional properties of the resulting whey protein concentrate. Neth Milk Dairy J 29. 198-211

Donovan M, Mulvihill DM (1987) Thermal denaturation and aggregation of whey proteins. Ir J Food Sci Technol 11, 87-100

Dubois M, Gilles K, Hamilton JK, Rebers PA, Smith F (1956) Colorimetric method for determination of sugars and related substances. Anal Chem 28, 350356

Fauquant J, Maubois JL, Pierre A (1988) Microfiltration du lait sur membrane minérale. Tech Lait Market $1028,21-31$

Gault P, Mahaut M, Korolczuk J (1990) Caractéristiques rhéologiques et gélification thermique du concentré protéique de lactosérum. Lait 70, 217-232

Gautier M, Rouault A, Méjean S, Fauquant J, Maubois JL (1994) Partition of Lactococcus lactis bacteriophage during the concentration of micellar casein by tangential $0.1 \mu \mathrm{m}$ pore size microfiltration. Lait 74 , 419-423

Gésan G, Merin U, Daufin G, Maugas JJ (1993) Performance of an industrial cross-flow microfiltration plant for clarifying rennet whey. Neth Milk Dairy J 47 , 121-135

Glover FA (1985) Ultrafiltration and reverse osmosis for the dairy industry. The National Institute for Research in Dairying, Technical Bulletin 5, Reading, UK

Harris JL, Pecar MA, Pearce RJ (1989) Effect of the processing equipment on protein functionality in the concentration of cheese whey by ultrafiltration. Aust $J$ Dairy Technol 44, 78-81

Joseph MSB, Mangino ME (1988) The effect of milk fat globule membrane protein on the foaming and gelation properties of beta-lactoglobulin solutions and whey protein concentrates. Aust J Dairy Techno/ 43, 9-11

Kim YA, Chism GW, Mangino ME (1987) Determination of the beta-lactogiobulin, alpha-lactalbumin and bovine serum albumin of whey protein concentrates and their relationship to protein functionality. J Food Sci 52, 124-127

Kinsella JE, Whitehead DM (1989) Proteins in whey: chemical, physical, and functional properties. Adv Food Nutr Res 33, 343-348
Mangino ME, Kim JH, Dunkerley JA, Zadow JG (1987) Factors important to the gelation of whey protein concentrates. Food Hydrocolloids 1, 277-282

Marshall KR (1982) Industrial isolation of milk proteins: whey proteins. In: Developments in dairy chemistry. 1. Proteins (Fox PF, ed) Applied Science Publishers, London

Maubois JL (1988) Whey, its biotechnological signification. In: Proc $8^{\text {th }}$ Int Biotechnol Symp, Volume II. (Durand G, Bobichon L, Florent J, eds) Société Française de Microbiologie

Merin U, Gordin, S (1983) Microfiltration of sweet cheese whey. NZJ Dairy Sci Technol 18, 153-160

Merin U, Cheryan M (1980) Factors affecting the mechanism of flux decline during ultrafiltration of cottage cheese whey. J Food Process Preserv 4, 183198

Morr CV, Ha YW (1993) Whey protein concentrates and isolates: Processing and functional properties. Crit Rev Food Sci Nutr 33, 431-476

Mucchetti G, Taglietti P (1993) Microbiological stabilization of whey by cross flow microfiltration. Lait 73 , $79-84$

Pearce KN (1977) The complexometric determination of calcium in dairy products. NZJ Dairy Sci Technol 12, 113-115

Peri C, Pompei C, Rossi F (1973) Process optimization in skim milk protein recovery and purification by ultrafiltration. J Food Sci 38, 135-140

Pierre A, Fauquant J, Le Graet Y, Piot M, Maubois JL (1992) Prèparation de phosphocaséinate natif par microfiltration sur membrane. Lait 72, 461-474

Pierre A, Le Graet Y, Daufin G, Michel F, Gésan G (1994) Whey microfiltration performance: influence of protein concentration by ultrafiltration and of physicochemical pretreatment. Lait 74, 65-77

Piot M, Maubois JL, Schaegis P, Veyre R, Luccioni A (1984) Microfiltration en flux tangentiel des lactosérums de fromagerie. Lait 64, 102-120

SAS (1985) User's guide: Statistics, Version 5 Edition, SAS Inst Inc, Cary, NC, USA

Rowland SJ (1938) The determination of the nitrogen distribution in milk. J Dairy Res 9, 42-46

Schmidt RH, Illingworth BL, Deng JC, Cornell JA (1979) Multiple regression and response surtace analysis of the effects of calcium chloride and cysteine on heat-induced whey protein gelation. J Agric Food Chem 27, 529-532

Shimada K, Cheftel JC (1989) Sulfhydryl group/disulphide bond interchange reactions during heat-induced gelation of whey protein isolate, I Agric Food Chem 37, 161-168

Swaisgood HE (1982) Chemistry of milk protein. In: Development in dairy chemistry-1. Proteins. (Fox PF, ed) Elsevier Applied Science Publishers, London

Trouvé E, Maubois JL, Piot M, Madec MN, Fauquant J. Rouault A, Tabard J Brinkmann G (1991) Rétention de différentes espèces microbiennes lors de l'épuration du lait par microfiltration en flux tangentiel. Lait $71,1-13$ 